\title{
Soluble urokinase plasminogen activator receptor and its complicated role in hemodialysis (HD) patients with Covid-19 infection
}

\author{
Ioannis Griveas ${ }^{1}$, Antonios Schoinas ${ }^{2}$, Anthi Balitsari ${ }^{3}$, Gerasimos Asimakopoulos ${ }^{4}$, \\ Evaggelos Pratilas ${ }^{5}$
}

${ }^{1}$ Medical Director and Consultant Nephrologist, ${ }^{2,3}$ Consultant Nephrologist, ${ }^{4,5}$ Resident in Nephrology, Nephrology Department, Army Share Fund Hospital of Athens, Greece, 417 NIMTS

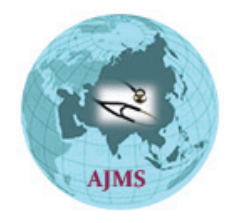

A B S T R A C T

Background: Soluble urokinase plasminogen receptor (suPAR) is a protein in the blood that has been described to reflect the severity status of systemic inflammation. Aims and Objective: We investigated the association between admission suPAR levels and severity and outcome of HD patients with Covid-19 infection. Materials and Methods: In an observational study of adult HD patients hospitalized for Covid-19, we measured suPAR levels in plasma samples. The time table for those measurements were as follows: at the beginning of admission, after hemoperfusion (HP) session for those patients that received them, and just before discharge. Results: Of the 17 patients ( 7 were male), 13 patients received HP (mean age: 74 years old). The median suPAR level was $12.94 \mathrm{ng} / \mathrm{ml}$. For those who undertook HP in HD unit median suPAR level was before session $12.95 \mathrm{ng} / \mathrm{mil}$ and $6.2 \mathrm{ng} / \mathrm{ml}$ at the end of each session $(p<0.05) .3$ patients had suPAR level below $7 \mathrm{ng} / \mathrm{ml}$. 2 of them survived without developing pleural effusions. 7 patients discharged from the hospital with median suPAR level $12.08 \mathrm{ng} / \mathrm{ml}$ which did not differ significantly from the median suPAR level of the diceased ones $(13.68 \mathrm{ng} / \mathrm{ml})$. Conclusion: Admission of suPAR levels in HD patients hospitalized for Covid-19 do not seem to be predictive for their clinical course in general. Chronic Kidney Disease and its relation to suPAR independently of patients' inflammation status may be the key component for our notice. Despite that, in patients where low levels of suPAR combined with absence of pleural effusions the prognosis was excellent.
http://nepjol.info/index.php/AJMS DOI: 10.3126/ajms.v12i7.36499

E-ISSN: 2091-0576

P-ISSN: 2467-9100

Copyright (c) 2021 Asian Journal of Medical Sciences

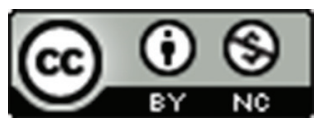

This work is licensed under a Creative Commons Attribution-NonCommercial 4.0 International License.

Key words: Hemodialysis; Covid-19; Soluble urokinase plasminogen receptor (suPAR)

\section{INTRODUCTION}

Soluble urokinase plasminogen receptor (suPAR) is a protein in the blood that has been described to reflect the severity status of systemic inflammation. It has been also connected with low grade inflammation. ${ }^{1}$ Our research team suggested that plasma suPAR concentrations may be a promising inflammation biomarker for HD population. We also noticed the existence of independent association of suPAR with nutritional status, anemia, mineral bone disease, hospitalization and mortality in HD population. ${ }^{1}$

At the same time, an elevated level of suPAR has been independently associated with incident chronic kidney disease. In particular, it has been reported that in patients with Chronic Kidney Disease (CKD), suPAR correlated with reduced Glomerular Filtration Rate $(\mathrm{GFR})^{2}$. It has been also demonstrated that suPAR provides prognostic data regarding cardiovascular events, mortality rates 
in general population, in critical patients and in HD population..$^{1-4}$

Covid-19 outbreak has been connected with increased circulating levels of D-dimers, fact that suggests endothelial activation. ${ }^{5}$ At the same time Covid-19 infection has been linked to several types of clinical presentation varying from low-degree fever or flu-like symptoms to severe respiratory failure. ${ }^{6}$ There are data from the literature that suggest suPAR may early trace patients with Covid-19 infection who will need intense immediate therapeutic intervention and also trace patients that expected to have milder clinical course. ${ }^{6,7}$

Considering all the above parameters and having under thought that HD population has a lot of specific features,

\section{AIMS AND OBJECTIVES}

We investigated the association between admission suPAR levels and severity and outcome of HD patients with Covid-19 infection.

\section{MATERIALS AND METHODS}

In an observational study of adults HD patients hospitalized for Covid-19 infection, we measured suPAR levels in plasma samples. In some of our patients we used resin-directed hemoadsorption cartridges (HA-330 and HA-130) manufactured by the Jafron Biomedical Company, China. This group of patients received hemoperfusion (HP) for 1-2 sessions in hemodialysis unit (HD) and 5 sessions in Intensive Care Unit (ICU). The time table for those measurements were as follows: at the beginning of admission, before and after hemoperfusion (HP) session for those patients that received them, and just before discharge. suPAR was measured by an enzyme immunoassay in duplicate (suPARnostic ${ }^{\mathrm{TM}}$, ViroGates, Lyngby, Denmark). Approval was obtained from the Institutional Ethics Committee prior to the commencement of the study.

\section{RESULTS}

Of the 17 patients ( 7 were male), 13 patients received HP (mean age: 74 years old), 12 patients in HD unit and one patient in ICU. Nine of seventeen patients were diabetic and 12/17 had known cardiovascular background.

The median suPAR level for all of our study group at admission was $12.94 \mathrm{ng} / \mathrm{ml}$. For those who undertook
HP in HD unit median suPAR level was before session $12.95 \mathrm{ng} / \mathrm{mil}$ and $6.2 \mathrm{ng} / \mathrm{ml}$ at the end of each session $(p<0.05)$. suPAR levels at the end of session in dialysate fluid (waste) was $5.9 \mathrm{ng} / \mathrm{mil}$.

One patient in ICU received 5 sessions of HP at the same time with CRRT. Three sessions during three consecutive days and one session after a week and then the fifth one after 3 days. In this case, median suPAR levels started from $15 \mathrm{ng} / \mathrm{mil}$ before each HP session, ended to $5.7 \mathrm{ng} / \mathrm{mil}$ in the end of the HP session and raised again to $15 \mathrm{ng} / \mathrm{mil}$ before nest session. Three patients had suPAR levels below $7 \mathrm{ng} / \mathrm{ml}$. 2 of them survived without developing pleural effusions or pulmonary inflitrates. Seven patients discharged from the hospital with median suPAR level of $12.08 \mathrm{ng} / \mathrm{ml}$ which did not differ significantly from the median suPAR level of the diceased ones $(13.68 \mathrm{ng} / \mathrm{ml})$.

\section{DISCUSSION}

Covid-19 pandemic and its unpredictable clinical course in many cases opened the discussion regarding early prognostic markers. Endothelial activation seems to have a crucial role in Covid-19 infection. Urokinase plasminogen activator receptor (uPAR) that is bound on the endothelium may be cleaved early during the disease course leading to an increase of its soluble counterpart, namely suPAR. ${ }^{8}$ On this basis, suPAR proposed as an early predictor of the risk of severe respiratory failure in Covid-19 patients, which could give physicians a tool to trace early patients that could benefit from intensified management. ${ }^{3,9}$

Covid-19 infection by its self and chronic kidney disease are entities which need closer insight regarding suPAR usefulness. suPAR, has been suggested to mirror the degree of immunoactivation and can be measured from blood, urine, saliva, or cerebrospinal fluid. ${ }^{10-12}$ In critically ill patients, several independent investigations have reported elevated suPAR in conditions of systemic inflammatory response syndrome (SIRS), bacteriemia, sepsis, and septic shock, in which high circulating suPAR levels indicated an unfavorable prognosis. However, this 'dogma' had been based on various studies investigating circulating suPAR levels in different disease etiologies, including sepsis, cardiovascular disorders, and cancer. ${ }^{3,13}$ At the same time, elevated suPAR has been linked with incident $\mathrm{CKD}$ and as promoting pathogenic factor for renal scarring in focal segmental glomerulosclerosis., ${ }^{2,14}$ 
Our patients had CKD under HD, cardiovascular disease background and diabetes as a major primary cause of their renal disease. Along with Covid-19 infection, they have a lot of contributable factors that may affect suPAR levels. This is the reason from our point of view that suPAR levels have not the same prognostic value in our study for Covid-19 patients as it has been mentioned otherwise. ${ }^{6}$ It has been pointed out that with HP sessions, suPAR levels decreased significantly. Due to suPAR molecular weight $(45-55 \mathrm{kd})$, it can be removed with hemadsorption cartridges that have been used. Another proof of that is the detection of suPAR in dialysate waste products. Thereby our findings support the view that suPAR could be used as a biomarker of clinical course of patients with Covid-19 and CKD. The tendency of increasing suPAR levels before next HP promotes the view of frequent and intense HP sessions in order to control inflammatory markers such as suPAR. How the decreased levels of suPAR correlates with improvement of Covid-19 infection is an issue open for further investigation.

Despite our previous comments, it has to be pointed out that we had 3 patients with suPAR levels below $7 \mathrm{ng} / \mathrm{ml}$ and 2 of them survived without developing pleural effusions or pulmonary infiltrates. It seems that low levels of suPAR in patients asymptomatic without pulmonary involvement have favorable prognostic value.

\section{CONCLUSION}

In conclusion, admission of suPAR levels in HD patients hospitalized for Covid-19 do not seem to be predictive for their clinical course in general. Chronic Kidney Disease backround and its relation to suPAR levels independently of patients' inflammation status may be the key component for our notice. Additionally, other comorbidities of our patients and lack of strong evidence regarding the importance of suPAR levels measurement and systemic inflammation provoke the need for further investigation. Despite that, in patients where low levels of suPAR combined with absence of pleural effusions the prognosis was excellent. Future clinical studies may therefore consider suPAR not only as an epiphenomenon but also as a potential therapeutic target in inflammatory disorders especially in combination with HP sessions.

\section{REFERENCES}

1. Griveas I, Andriopoulos C, Sitaras P and Aktsiali M. Soluble urokinase plasminogen receptor: a future risk marker for hemodialysis patients. Nephrol Dial Transplant. 2015; 30Issue suppl_3: Page iii624.

https://doi.org/10.1093/ndt/gfv200.66

2. Hayek SS, Sever S, Ko YA, Trachtman H, Awad M, Wadhwani S, et al. Soluble urokinase receptorand chronic kidney disease. N Engl J Med. 2015;373(20):1916-1925.

https://doi.org/10.1056/NEJMoa1506362

3. Eugen-Olsen J, Anderson $\mathrm{O}$, Linneberg $\mathrm{A}$, Ladelund $\mathrm{S}$, Hansen TW, Langkilde A, et al. Circulating soluble urokinase plasminogen activator receptor predicts cancer, cardiovascular disease, diabetes and mortality in the general population. J Intern Med 2010; 268:296-308.

https://doi.org/10.1111/j.1365-2796.2010.02252.x

4. Koch A, Voigt S, Kruschinski C, SansonE, Duckers H, Horn A, et al. Circulating soluble urokinase plasminogen activator receptor is stably elevated during the first week of treatment in the intensive care unit and predicts mortality in critically ill patients. Crit Care. 2011;15(1): R63.

https://doi.org/10.1186/cc10037

5. Guan W, Ni ZY, Hu Y, Liang WH, Ou CQ, He JX, et al. Clinical characteristics of coronavirus disease 2019 in China. N Engl J Med. 2020;382(18):1708-1720.

https://doi.org/10.1056/NEJMoa2002032

6. Rovina N, Akinosoglou K, Eugen-Olsen J, Hayek S, Reiser J and Giamarellos-Bourboulis EJ. Soluble urokinase plasminogen activator receptor (suPAR) as an early predictor of severe respiratory failure in patients with COVID-19 pneumonia. Crit Care. 2020; 24: 187.

https://doi.org/10.1186/s13054-020-02897-4

7. Mingxiang $H$, Linlin L, Jianshan S, Yao W, Rui W, Cai $Y$, et al. Plasma levels of the active form of suPAR are associated with COVID-19 severity. Crit Care. 2020;24(1):704.

https://doi.org/10.1186/s13054-020-03336-0

8. Schultz M, Rasmussen LJH, Høi-Hansen T, Kjøller $E$, Jensen BN, Lind MN, et al. Early discharge from the emergency department based on soluble urokinase plasminogen activator receptor (suPAR) levels: a TRIAGE III substudy. Dis Markers. 2019; 3403549.

https://doi.org/10.1155/2019/3403549

9. Mehta P, McAuley DF, Brown M, Sanchez E, Tattersall RS and Manson JJ. COVID-19: consider cytokine storm syndromes and immunosuppression. Lancet. 2020;395(10229):1033-1034. https://doi.org/10.1016/S0140-6736(20)30628-0

10. Eugen-Olsen J. suPAR - a future risk marker. J Intern Med 2011, 270(1):29-31. https://doi.org/10.1111/j.1365-2796.2011.02372.x

11. Rabna P, Andersen A, Wejse C, Oliveira I, Francisco Gomes V, Bonde Haaland $M$, et al. Urine suPAR levels compared with plasma suPAR levels as predictors of post-consultation mortality risk among individuals assumed to be TB-negative: a prospective cohort study. Inflammation. 2010; 33:374-380. https://doi.org/10.1007/s10753-010-9195-2

12. Tzanakaki G, Paparoupa M, Kyprianou M, Barbouni A, EugenOlsen $\mathrm{J}$ and Kourea- Kremastinou J. Elevated soluble urokinase receptor values in CSF, age and bacterial meningitis infection are independent and additive risk factors of fatal outcome. Eur $\mathrm{J}$ Clin Microbiol Infect Dis. 2012;31(6):1157-1162. https://doi.org/10.1007/s10096-011-1423-7

13. Langkilde A, Hansen TW, Ladelund S, Linneberg A, Andersen O, Haugaard SB, et al. Increased plasma soluble UPAR level is a risk marker of respiratory cancer in initially 
cancer-free individuals. Cancer Epidemiol Biomarkers Prev. 2011;20(4):609-618.

https://doi.org/10.1158/1055-9965.EPI-10-1009

14. Wei C, El Hindi S, Li J, Fornoni A, Goes N, Sageshima J,
Maiguel D, et al. Circulating urokinase receptor as a cause of focal segmental glomerulosclerosis. Nat Med. 2011;17(8):952-960.

https://doi.org/10.1038/nm.2411

\section{Author contributions:}

IG- Measuring Soluble urokinase plasminogen receptor and statistical analysis; AS- Measuring Soluble urokinase plasminogen receptor and data collection; AB-Data Collection; GA, EP- Data Collection.

\section{Work Attributed to:}

Nephrology Department, Army Share Fund Hospital of Athens, Greece, 417 NIMTS

\section{ORCID ID:}

Dr. Griveas loannis- (i) https://orcid.org/0000-0003-3588-8532

Dr. Antonios Schoinas- (1) https://orcid.org/0000-0002-5836-7601

Dr. Anthi Balitsari- (D https://orcid.org/0000-0001-6951-0875 